\title{
"Ways of Doing" Developed by Biology Teachers as a Production of School Knowledge
}

\author{
Edinaldo Medeiros Carmo ${ }^{(1)}$ Brazil \\ Sandra Escovedo Selles ${ }^{(1)}$ Brazil
}

This research focuses on the relationships between teacher knowledge and the teaching content with which biology teachers deal in their daily teaching practices. This research seeks to understand the ways teachers use this knowledge to facilitate students' learning of biology. The methodological guidelines of the present study have been inspired on experiences of ethnographic studies to combine different procedures of data collection: questionnaires; interviews and classroom observations with field notes and video recording. The empirical design involved three public secondary schools, placed in the urban area of Vitória da Conquista, Bahia with the participation of six biology teachers. In this work, throughout a triangulation process, the data produced with three of those six teachers were analyzed by means of a thematic content analysis, which allowed the identification of words, sentences or summaries, and a range of relationships present in the data. The results indicate that, in the production of school knowledge, teacher knowledge is translated into practice by a combination of different "ways of doing", favoring students' learning of biological contents. In this sense, these "ways of doing" indicate links between teacher knowledge and the biological content. The results also indicate that such links are results of teaching established routines within the school culture. The research argues that "ways of doing" are the outcomes of a more specific teacher's experiential knowledge, that when articulated to other types of knowledge, shape the production of school knowledge.

Keywords: School knowledge; biology teachers; Teacher knowledge.

\section{Introduction}

Since the end of the 1980s, studies on teacher knowledge and school knowledge have enabled new ways of understanding pedagogical practices, notably because they adopt a non-normative perspective, experimenting with and broadening ways of listening to teachers (Monteiro, 2007). In this sense, such perspectives are opposed to views that do not value the context in which these practices are built and fall into criticism about the lack of teachers' mastery on the different kinds of knowledge to be taught, as well as the reasons for the failure of teaching. Thus, departing from perspectives and visions such as those demand research skills that do not focus on judgments about teaching practices or that build an ideal teacher. This is because focusing studies on a given value judgment of teaching practices restricts the possibilities of understanding these practices - or, at 
best, drastically reduces them - and therefore the understanding of the elements that constitute them.

It must be considered that literature has historically pointed to the fragility of exclusively associating the role of School Education teachers to the domain of knowledge transmission techniques validated by reference sciences (Shulman, 1986, 1987; Gauthier, Martineau, Desviens, Malo, \& Simard, 2006). This is due to the assumption that it is necessary to know the subject to be taught, and its transmissive techniques in itself would support the teaching action. Focusing on the technical domain and on the content itself tends to disqualify the practices that happen every day in schools when these are not configured in a given quality reference idealized by such frames. Without denying that content knowledge is one of the foundations of a teacher's daily action, there are inventive modes of teaching that are not limited to certain standards.

In this article, we set dialogues between teachers' daily practices with studies related to teacher knowledge and school knowledge ${ }^{1}$. We aim to understand how biology teachers approach their knowledge to make biological content teachable to students, considering the links between the knowledge enacted in pedagogical practices and the teaching objects, that is, the school content with which these teachers deal in their teaching contexts. Another aim of this study is to produce research material that, on the one hand, is opposed to an understanding of pedagogical practices and the teaching profession as limited to the content domain and, on the other hand, presents teaching modalities referenced by teachers' production in the classroom. In particular, we chose biology classes to present them as instances of school knowledge construction, as a context in which teachers approach knowledge from diverse sources. It is likewise a purpose of this article to adopt the visibility of teachers' professional activity in the classrooms as a way of accessing the knowledge and practices that they produce, based on epistemic references placed in dialogue with empirical data.

\section{What the one who teaches knows: the issue of teacher knowledge and school knowledge}

In an article published in 1986 in the Journal of Education for Teaching, Maria das Graças Feldens presents a state of the art research on teacher education in Brazil using articles, theses, dissertations and research reports from graduate programs across the country. Setting a historiography of Brazilian research on teacher education in the country since the creation of the Instituto Nacional de Estudos e Pesquisas Educacionais Anísio Teixeira (INEP) ${ }^{2}$ at the end of the 1930s, the author elects the period between 1972 and $1981^{3}$ to analyze both quantitatively and qualitatively the production of research: 170 theses and dissertations and 125 articles published in journals, of which

1 This article integrates a broader research, which resulted in the doctoral dissertation of Carmo (2013).

2 A National Institute of Educational Studies and Research in Brazil.

3 The choice of period was based on the fact that the development of graduate programs in education began with the creation of the first courses from 1971 on. 
only 35 provides empirical research results (Feldens, 1986, p. 88). From the analysis of this production, the author presents her conclusions highlighting the lack of research, the absence of theory about teacher education and its theoretical development, and the discrepancies about research purposes and priorities of this theme. As she writes during the fading lights of the military dictatorship in our country, Feldens ends her article by acknowledging that "[the time and context in the Brazilian educational community are favorable to changes in teacher education [...] in a direction very different from that taken in the past [...] ", and asks:" Will we be able to take advantages of the situation and improve the state of the art in teacher education? “( p. 95)

The picture described by Feldens (1986), in a way, is in line with the reflections of Lee Shulman $(1986,1987)$. When comparing the first teacher education courses that he taught three decades earlier, the author points out that his understanding of student learning was quite simple, but it became more complex with the contribution of theories that deconstructed technical notions about learning processes. Guided by simplistic conceptions about such complex processes, teacher education - which is referred by Shulman and investigated by Feldens - framed theory and subjects with implications for teaching processes. It is relevant to highlight that technical-based pedagogies had a strong presence in undergraduate courses at the time, dominated by the guidelines enumerated by Dominique Colinvaux: "[...] to scientists, it was necessary to indicate what to teach; psychologists determined when to teach and, finally, educators were responsible for elaborating how to teach" (Colinvaux, 2008, p. 3, author's emphasis). Thus, those courses were strained, on the one hand, by the scientific vigilance of the rigor and timeliness of contents to be taught and, on the other hand, by cognitive psychology that indicated the moment considered "appropriate" for such contents to be taught and learned by the students. The pedagogical textbooks adopted in undergraduate courses constrained teacher education among those academic domains. Referring to the research programs on teaching and learning of the 1950s and 1960s, Colinvaux's reflection is also in line with the studies on teacher education analyzed by Feldens (1986), as they were impacted by curriculum efficiency standards, reducing the teacher to a technical subject whose knowledge could be questioned: whether or not they mastered an academic knowledge and techniques of transmission. It was, therefore, a knowledge sidelined to other kinds of knowledge apart from actual teaching practices, and externally conditioned in an irreducible way.

Such scenario began to be challenged in the late 1980s, especially when educational researchers such as Lee Shulman, Clermont Guathier, Maurice Tardif, Claude Lessard, and others began to enunciate teacher knowledge not seen in technical perspectives. The validity of pedagogical technicality was questioned, not only as a conception of teaching and learning that guided teacher education, but also because it was necessary to bring to the center of the debate "the question of status and social recognition of teaching" (Lessard, 2013, p. 228). Tardif (2014) highlights this while discussing the relationship

4 Our translation 
between professionalism and teaching knowledge, in what he calls the "condition of a new professionalism". For Lessard (2013, p. 228), the debate on teacher professionalism cannot continue to be apart from the epistemic recognition of teacher knowledge:

Which kind of knowledge is at the basis of teaching? Is it tacit, implicit knowledge that we never talk about and learn at work? Or is it an "objectifiable" and therefore transmissible knowledge base that could enable teachers to claim a status of a true profession? The question of knowledge then came after the statute. ${ }^{5}$

The body of research developed by these authors, namely, the Portuguese translations of many of their works, constituted a research initiative appropriated by the educational community, as documented by Ana Maria Monteiro (2007). The refusal to consider that teachers would be merely transmitters of knowledge produced by other groups repositioned the objects of research on teacher education, contrasting with the interests presented by Feldens (1986). The epistemic dimensions of these kinds of knowledge gradually became accepted by Brazilian researchers, probably as responses to what had been announced by Feldens when discussing the theoretical weakness of research on the subject conducted until the 1980s.

The interest in identifying the appropriation of this research strand in Brazil during the 1990s unfolded in the object of study presented by Célia Nunes (2001). For the author, the understanding of teaching practice and its body of knowledge, although in a "timid" way, meant a "shift" in studies that started to analyze teacher education and professional development. This formulation boosted research, "[...] in a search to identify the different kinds of knowledge implicit in teaching practice" (p. 29). In detailing the different references and the theoretical-methodological approaches that underlie these studies, as well as the typologies used and created by Brazilian researchers, Nunes study recognizes an investigative course developed with "[...] its own characteristics, but aligned with a tendency on research about education and teachers" (p. 38). Nunes observes that teacher knowledge has been expressive in educational areas, such as the field of didactics and curriculum, taking as reference the analysis of the academic production recorded in the Proceedings of the National Association of Graduate and Research in Education (ANPEd) ${ }^{6}$. Moreover, the author points out that until twenty years ago, the literature did not present empirical studies willing to understand the transformations of theoretical knowledge enacted in the practical dimension.

In order to discuss the issue of teacher knowledge in the area of Science Education, it is worth asking, as in the study by Nunes (2001), if the trend brought by authors of international scope has also been unfolded in objects of study of Brazilian researchers in this area. The interest of examining the appropriation of teaching knowledge as an object of research in Science and Biology Education in Brazil led Bonfim-Silva and Carmo (2016) to carry out documentary research in the Catalog of Theses and Dissertations of

5 Our translation

6 Anais da Associação Nacional de Pós-Graduação e Pesquisa em Educação. 
the Coordination for the Improvement of Higher Education Personnel (CAPES) 7 and in the Public Domain Portal, in order to identify the productions published between 2005 and 2012. In the former, 35 productions were identified and, in the latter, 102 pieces of research. In a total, the authors examined 30 academic productions, being 27 master thesis and 3 doctoral dissertation. Quantitatively, there is a prevalence of studies related to the practice and training of teachers who work in Early Childhood Education and first years of Secondary School, highlighting the pedagogical dimensions in the process of content-teaching. However, when the studies involve teacher education courses of Biological Sciences, it was verified that the discussion presented in these studies only touched on didactic-pedagogical aspects of biological contents to be worked in School Education.

Both the studies by Nunes (2001) and Bonfim-Silva and Carmo (2016) explain the conceptual framework of research on teacher knowledge, in addition to the criticisms they bring to the technicist-rational approach. Alongside the reflections of Tardif (2014) and Gauthier et al. (2006) on the different types of teacher knowledge, the documented pieces of research also approached studies by Shulman $(1986,1987)$ that problematized the so-called Knowledge Base for teacher education, emphasizing what the author conceptualized as "Pedagogical Content Knowledge" (PCK). For Gauthier et al. (2006), teacher knowledge makes teachers the protagonists of the work they perform in their schools, which directs the investigative focus to these modes of production:

If the teacher is an agent of primary importance in the pursuit of educational excellence, and if the unveiling of the knowledge he uses is a condition for professionalization, what then are the practices, the knowledge, and the skills that increase the effectiveness of teaching? Answering this question means, in a way, to identify a repertoire of knowledge specific to the teacher's role (Gauthier et al., 2006, p 61) ${ }^{8}$.

Aligned with what is proposed by the Canadian researchers, Shulman (1987) also highlights the need to investigate this repertoire while formulating the teaching knowledge base as "a codified or codifiable aggregation of knowledge, skills, understandings, and technology, of ethics and disposition, of collective responsibility" (p. 4). The author presents three categories that constitute the knowledge base of the teacher: content knowledge; pedagogical content knowledge, and curricular knowledge. The first category - content knowledge - refers to the specific knowledge of the area, which the teacher has studied. The pedagogical content knowledge, which relates not only to the knowledge to be taught, but also how it should be taught to foster students' learning. The third category, the curricular knowledge, is concerned with the contents to be taught, selecting teaching materials and methodologies appropriate to teaching practices. For the author, the teacher's knowledge base is foregrounded on four main sources which are intrinsic to the teaching work, which are scholarship in content disciplines, which relates to the field of knowledge; educational materials and structures, based on the teacher's knowledge

7 Coordenação de Aperfeiçoamento de Pessoal de Nível Superior.

8 Our translation. 
about the instrumental resources and the institutional conditions where teaching takes place; formal educational scholarship; and wisdom of practice, meaning the knowledge proper to practice (Shulman, 1987, p. 8-12).

The modes of appropriation of those sources are, according to the author, a typical school production, not directly depending on a set of knowledge apart from teaching practices, because if teachers make use of such body of knowledge, in turn, they also transform it in the course of their professional trajectory. In other words, it is in the practical dimension that the translation of such knowledge is materialized into school productions, reinforcing a knowledge produced by teachers within the scope of their professional performance.

The research traditions that deal with the productive nature of teacher knowledge have heuristic significance when placed in dialogue with the curricular perspectives that recognize the school knowledge 9 . According to Tardif (2014), the study of teacher knowledge has given greater visibility to central questions, such as school and teachers, in the transmission of school knowledge, which does not reduce it to purely simplified scientific knowledge. At school, teachers deal with informal knowledge (lessons in citizenship, ethics, morals, etc.) and share with other institutions the constitution of such body of knowledge; however, the school is the only one that has the mission of transmitting it in a formal context of schooling. In justifying the importance of centralized studies in school, this author meets Forquin's (1993) formulations, when he points out that education is built in a process of selection within a culture and in a re-elaboration of contents aimed to be transmitted to new generations. To make it socially available, a process marked by "an immense work of reorganization, restructuring" (p.16) must take place. The author understands that this process: "[...] imposes the emergence of specific configurations (typically school-based ways of knowing and ways of thinking). [...] a kind of 'school culture' suis generis, endowed with its own dynamics and able to leave the limits of the school [...]" (p.17), to sustain other social dynamics, becoming a formative force of habits in society.

The "relative specificity" of school culture leads Forquin to understand it as a "set of cognitive and symbolic contents" that supports systematic learning for formative purposes, in which the contents are "[...] selected, organized, standardized, routinized under the effect of pedagogical imperatives" (p. 167). Lopes and Macedo (2011, pp. 9495) share this understanding when they state that: "[...] a curricular knowledge or school knowledge or pedagogical discourse is a kind of content produced for pedagogical purposes, be they in an institution with specific purposes for this - the school - or in any process of cultural production and reproduction." The pedagogization of scientific

9 In the context of the New Sociology of Education (NSE), with the Institute of Education from the University of London, sociologists Basil Bernstein, Michael Young, and other intellectuals, directed their criticisms on the efficiency and technicist curriculum principles. Their theorizations revealed the ideologies that focused on technicist rational formulations (Monteiro, 2007). It can be assumed that curricular studies that followed the NSE began to accept different problems that opened the schools black box and allowed to theoretically challenge the conception of teachers as transmitters of externally produced knowledge. 
contents, when permeated by a unique school culture, is expressed through what Forquin $(1992,34)$ calls "morphological and stylistic traits", which are characteristic of school knowledge. Among these traits, the author emphasizes: predominance of values in the presentation and clarification of contents; concern for progressiveness; importance attributed to formal division of contents (chapters, lessons, parts and sub-parts); excessive redundancy; use of periphrastic resources in explanatory comments, glosses and condensation techniques (summaries, syntheses and mnemonic techniques); effort to materialize content through illustrations, schematizations and examples; and, finally, use of questions and exercises that often assume the function of control or reinforcement.

The mechanisms of curricular selection rely on the involvement of several actors in different social spheres; however, it is in the daily work of the teacher that such processes gain concreteness. It could be said that it is through the confluence among multiple curricular selections, which inform the body of knowledge socially legitimated, that teacher knowledge is approached. After all, the choices of what and how to teach certain content in a specific classroom, in a school discipline of its own, except for very special situations, lie in the decisions of teachers. The aspects that cross the disciplinary practice in the school, besides the selection and organization of the contents, involve mediating devices that transform objects to teach in teaching objects, and it is in the school that this practice materializes as a space of knowledge and culture production (Forquin, 1993).

The theoretical reflections that recognize the teaching practice as a productive instance open the possibilities of empirically exploring processes that engender such production. For this, in this study we also deal with the concepts of "strategies" and "tactics" elaborated by Michel de Certeau, for they bring particular contributions to this study. Certeau (2014) points out that "ways of doing" - reading, living, talking, circulating, etc. - present possibilities for modifications through tactical uses that subjects make in their daily lives. In this sense, he conceptualizes tactics as the wits used by the subjects to reconfigure what is prescribed by the strategies. The author differentiates tactics from strategies by stating that the former "are the types of operations in those [social] spaces where strategies are means of producing, mapping and imposing, whereas tactics can only use, manipulate and change them ${ }^{10}$ " $(2014$, p. 87, author's emphasis). In arguing about the use of tactics, he emphasizes that similarly to literature in which it is possible to distinguish different forms of writing, it is also possible to perceive "ways of doing" in different daily acts. Another difference highlighted by the author concerns power relations, in which "Without a proper place, without a globalizing vision, blind and insightful as one gets a face-to-face experience, without distance, commanded by the vagaries of time, the tactic is determined by the absence of power, just as strategy is organized by the postulate of power ${ }^{11 "}$ (Certeau, 2014, p. 95, author's emphasis). Thus, in power relations that cross schools and classrooms, teachers create tactics within their

10 Our translation.

11 Our translation. 
practices, being able to subvert the prescribed curriculum - considered as strategies coming externally to the teaching action - to reconcile what is imposed in the real working conditions to their needs and those of their students.

Thus, the understanding of tactics is not reduced to a technical domain of translation of what is imposed, or mere reaction, as if nothing more was expected from the teacher than masking rules and simulating behaviors. It is about understanding tactics as a teaching production, induced by strategies elaborated in instances that idealize the teaching action, that is, a reconfiguration that responds to what is preconized, interpreting it as a means to know and face its fragilities. For this study, we understand that tactics are operations that result in teachers' "ways of doing" in biology classes. Inspired by the "know-how" coined by Tardif (2014), and in dialogue with the "art of making" in everyday life, conceptualized by Certeau (2014), we employ "ways of doing" to mark the procedural character that these tactics occupy in the practice of the participants in this study.

Based on these reflections and dialogues with the authors, we situate the object of our investigation in the daily practices of biology teachers, since we aim to understand the established links between the knowledge displayed in the exercise of teaching and the teaching objects in their daily work. Our research hypothesis emphasizes the teacher as an actor in the production of school knowledge in which teacher knowledge, from different sources, is also approached, transformed and fabricated in the intersubjective relations that take place in the space of the classroom. This dynamic process is expressed through didactic procedures, activities, explanations, examples, including the various mechanisms of selection and intervention that permeate the pedagogic practice.

\section{Methodological paths}

The nature of the investigations involving teaching and, by inclusion, teacher knowledge, is complex and, therefore, demands a methodological approach that captures its multifaceted aspects. The analysis carried out by Cecília Borges (2001,p. 72) emphasizes a "conceptual and methodological diversity of the field", since studies "are affiliated to different theoretical-methodological traditions", contradictorily exhibiting both "an aspect of maturity of the field" as well as "an aspect of cloudiness". Such complex nature poses challenges to the "more refined conceptualization of the object studied". In turn, Gauthier et al. (2006), when analyzing the theoretical and methodological orientations of research on teacher knowledge, organizes them under three approaches: productprocess; cognitive; and subjectivist-interactionist ${ }^{12}$. Among the three approaches, the latter is influenced by phenomenology: "[...] around the notions of representation and interaction", because "[...] objects have no meaning in themselves; their meanings derive from the act of appropriation of lived experience" (p.162). For the authors, the subjectivist-interactionist approach is what allows us to "better understand a

12 We chose to use the approaches elaborated by Gauthier et al. (2006). We recognize, however, that authors who study teacher knowledge propose other ways of organizing such approaches. 
phenomenon as complex as the teacher-student interaction in teaching situations" ( $\mathrm{p}$. 166), because " $[. .$.$] it is based on the premise that individuals are beings of 'stories', beings$ who construct their representations of the world by interacting with others" (p.162). In addition, they conclude that "in the research of teaching knowledge repertoire, the most significant contribution of the subjectivist-interactionist conception is to take into account the complexity of the interactions within the classroom", because it provides "[...] elements particularly rich in the complex nature of teaching knowledge" (p.161).

Consistent with this approach, this research was carried out taking into account assumptions such as the recognition of the complexity of teaching practices, and also the existence of enacted knowledge in it, as suggested by Monteiro (2007). Following this perspective, the methodological orientations of the ethnographic studies discussed by André (2003) were taken into consideration so as to combine different procedures of data collection, including visits and stays in schools during the months of April to November 2010, when field research was conducted. The study involved three public state secondary schools located in the urban area of Vitória da Conquista, Bahia.

The identification of the teachers who participated in the research was based on students' reports on the curricular components related to the Teaching Practice of the Undergraduate Course in Biological Sciences of the State University of the Southwest of Bahia $^{13}$ (UESB) and testimonies of teachers who work at public state schools. Similarly to the study by Confortin and Caimi (2017) we sought to identify teachers who "[...] had their practice marked by transcendence to the lacunar aspects of pedagogical activity ${ }^{14}$ " (160). That is, those who, despite the multiple interactions that occur in the school, channeled efforts to improve teaching, considering that the teacher, as asserted by Tardif (2014, p. 39), "[...] must know the subject, the discipline and the program, as well as certain knowledge related to the sciences of education and pedagogy, and to develop a practical knowledge based on daily experience with students ${ }^{15}$.

We thus looked for teachers who carried out "creative activities", that is, practices associated with methodologies that privilege participation and involvement of students and that enhance teaching and learning. This denomination is coherent with the orientations of the studies on teacher knowledge within the subjectivist-interactionist approach, since it does not establish an a priori value to teachers, often referred to as "good teachers". Such approach does not leave behind aspects of teaching practice that are in accordance with the purposes of this research. With that in mind, we understand that the suggestions provided by UESB peers and their students were not solely based on idiosyncratic opinions, but provided legitimacy to the identification of teachers who performed "creative activities". This is because such indications relates to the phenomenological aspects pointed out by Gauthier et al. (2006, p. 161), for they reaffirm the teacher as " $[. .$.$] a being who constructs his or her representations of the world by$ interacting with others".

13 Universidade Estadual do Sudoeste da Bahia

14 Our translation.

15 Our translation. 
After gathering students' suggestions, the choice of the participants encompassed six of them, whose compatibility with the research objectives and the theoretical framework implied in the following criteria: (a) effective link in the public system of education; (b) Biological Sciences initial teacher training; (c) experience in teaching Biology for five years or more; and, mainly, (d) implementation, on a regular basis, of "creative activities". As a last criterion (e), teaching experience between five and ten years, approaching the "stabilization and consolidation phase", as pointed out by Tardif (2014, p. 85), and teachers with more time in the teaching trajectory.

Throughout the article, we present the productions of three out of the six teachers who participated in the study, identified here with pseudonyms. The option to present only data from three teachers lies on the fact that, in the sources surveyed, these were the teachers who explicitly showed aspects related to the production of school knowledge, a category that we discuss in this article.

In particular, the teachers chosen were Sônia who had twenty-five years of experience at the time of the research, sixteen of which were in biology teaching. In her professional career, she has gone through several stages of School Education, in which she worked with the initial and final grades of Elementary School, Secondary School, in the Adult Education modality, and also, in administrative duties, always in the public school system.

With eight years of professional activity in teaching biology and four of them also in science teaching, teacher Sérgio worked in the state and municipal education system and also in the private initiative with specific disciplines of biology for technical courses in the area of health. Teacher Nilton, on the other hand, had seven years of teaching practice, five of them with the subject of biology. It is worth considering that the three teachers - Sônia, Sérgio and Nilton - had a 60 hour work load per week.

Initially, we visited the schools to present a research proposal to those teachers who, after having accepted to participate, signed the Free and Informed Consent Term. For the production of data, we first administered a questionnaire - in order to trace the profile of the group surveyed - and also interviewed them for about fifty minutes, with the objective of addressing more specific issues related to the teaching profession, the choice for the profession and their professional path. Another data-gathering procedure was based on classroom observation during a teaching unit, along with field notes and video journaling, which allowed us to return to the schools for a second interview, with the objective of discussing in a more detailed way issues related to the previous interview, but, mainly, those moments allowed us to analyze together the classroom observation records and to discuss the choices and methodological procedures adopted by them.

Using a triangulation process, the data produced was analyzed through Content Analysis (Minayo, 2014). We chose to use thematic analysis because the theme allowed us to identify, through words, phrases or summaries, the range of relations present in the interview. By exploring the enactment of teacher knowledge and the production of school knowledge, the content of class observations and interviews defined the 
category and subcategories of analysis, which allowed us to identify the traits of school knowledge production in the practices studied. Thus, in the process of analysis, the categories emerged from the empirical field, in dialogue with the theoretical framework of the present study, articulating directly with the research question. While examining teaching practices to correlate teacher knowledge and school knowledge production, we explored the body of knowledge materialized in teaching practices and its relationship with teaching objects.

\section{Examining "ways of doing" of biology teachers}

In teaching processes, teachers use different means to make curricular knowledge teachable to students, that is, the "know-how" dimension, as nominated by Tardif (2014), gains a centrality in these processes. In this movement, teachers enact different kinds of knowledge, moving from those produced in their personal and professional trajectories to those appropriate in the course of teacher education and teaching experience. It is the ways in which these types of knowledge are used that we will now analyze, trying to identify the traits of school knowledge production in the "ways of doing" employed by biology teachers during the teaching process. Thus, we organize these results around the category "Examining 'ways of doing' of biology teachers" articulated into three subcategories: approaching biological contents in the reading of the textbook; the use of images, schemes and exercises from the textbook; and, the construction of explanatory schemes or drawings to produce syntheses of teaching contents. In each of these subcategories we will highlight the teachers' "ways of doing", understanding them as "tactics" that represent teachers' creations in the re-elaboration of "strategies" brought to their professional practice. To do so, we will analyze the data generated in the research in light of the concepts developed by authors in the field of teacher education and curriculum.

\section{Approaching biological contents in the reading of the textbook}

In the course of the research, we hoped that the textbook would be an instrument widely used by teachers, since literature is emphatic in affirming the prevalence of its use in schools (Megid-Neto, \& Fracalanza, 2003). However, in the set of classes observed, textbooks were employed by some teachers and in specific moments. For instance, the use of the biology textbook happened in different situations and for different purposes, including readings (collectively or in small groups), queries of images or explanatory schemes, among others, as in the following episode, focusing the data produced by teacher Sônia.

In the course of two classes, approximately ninety minutes, teacher Sônia used the textbook for reading. In both moments, the content was "biological evolution", being the starting point to depict the primitive atmosphere. Sônia started the class by asking students to form a large circle and then asked one of them to read the textbook to the whole class. During the reading, the teacher paused to explain what the student had 
read. At times, she re-read the part of the text she would like to emphasize and then explained its content. In the following class, the teacher again used the textbook, reading the text herself. In situations where she realized that a particular student was distracted or talking to other classmates, she would ask him or her to continue reading or, at other times, she would raise some questions. At the end of each paragraph, also in that class, the teacher interrupted the reading and questioned students, exploring the information brought in the text.

During the collective reading of the textbook, Sônia made use of different types of knowledge, not only to explain the content addressed, but also to involve the class in the discussion. Upon noticing any distraction from the students, she would ask them to take over as readers in the group, or to respond to questions. Throughout the reading and explanations, she often questioned them, which allowed her to identify the previous knowledge about the contents addressed and, from there, to problematize and contextualize the content being taught. She did this by asking questions related to the students' daily experiences, interweaving information related to health, well-being, and environmental issues. It showed, therefore, that the teacher's practice observed was marked by didactic intentionality, as Forquin (1993) and Tardif (2014) point out. With the purpose of facilitating the process of teaching and learning, this movement fostered students' participation, which allowed the teacher to have their attention during the lesson. In order to help students to understand the contrasts between the conditions of the primitive and the current atmosphere, the teacher enacted not only knowledge about the subject matter, but also established relationships with environmental issues in a contextualized and reflective way. The episode seems to make explicit that Sônia invented a proper "way of doing" for the use of the textbook in her class. This is a possibility of analysis fertilized by Certeau's contribution (2014), when he reverses the way to interpret cultural practices, referring to the "invention of everyday life", addressed by the author as "arts of making", "subtle guile", "resistance tactics", which alter objects and codes.

The analysis of this episode also shows that the teaching action has some conditioning factors that arise from the organization of work and the interactive nature of teaching, and interfere directly in the pedagogical action. For Tardif (2014, p. 49), these constraints are not abstract, but "[...] related to concrete situations that are not subject of finished definitions and which require improvisation and personal ability, as well as the capacity to face situations more or less transient and variable ${ }^{16}$. In this sense, as stated by Gauthier et al. (2006), teacher work is crossed by two fundamental dimensions: the management of the subject matter (instruction) and classroom management (to organize the class, to establish rules and ways of proceeding, to react to excesses related to student's behavior, etc.). These two dimensions, therefore, do not overlap or subordinate

16 Our translation. 
each other, as in the episode analyzed, since Sônia both invents a way of managing the biological content and organizes her class while using the textbook.

In addition to that, the analysis shows that only knowing and mastering the subject matter and curricular knowledge related to biological content knowledge is not sufficient to sustain the teaching activity. Surely, Sônia approached knowledge of professional training, subject matter knowledge, curricular knowledge, but also (and above all) experiential knowledge (Tardif, 2014). In the classroom context, time and space in which different events intersected - for instance, the distraction of the students - the teacher found immediate alternatives so the ritual of the class would not be undermined, but instead, could be better profited. In the situation under analysis, through questioning and answers, the teacher managed to involve students, allowing them to identify their knowledge about the content, therefore following a planned action at that moment. We argue that the knowledge derived from professional experience was shaping the conduction of the lesson. In other words, by approaching the reading of the textbook, a device so familiar to the school culture, it was the class management that evidenced the experiential knowledge of Sônia. Thus, we highlight the plural and heterogeneous nature of teacher knowledge, as defined by Tardif (2014), because they are made up of different sources and operate with different goals, according to a certain pragmatism, since they are in the service of an action that is permeated by context and by other subjects involved: the students. Sônia showed that the class was not in the service of the textbook, or the content about primitive atmosphere, but the meaning that the students could assign when using this curriculum material.

When we explore the different sources that support Sônia's "ways of doing", we identify that her questions about the local context were related to her concern with the students' critical education. To get to this conclusion, we used the content of an interview conducted in the initial period of field research, prior to classroom observation. In the narrative, by intermingling the data produced in the classroom and in the records from the interview, we highlighted the concern with students' critical education, but we also stress that the way Sônia enacts her knowledge is built through the relation with teaching objects:

So, in addition to this search for an education that caters for the construction of a conscious citizen, I also feel that this whole trajectory of years of pedagogical practice, of being always, every day, with each coming group, through each passing year, I feel also confident, let's say a confidence in terms of content knowledge. [...] such trajectory in the classroom, this whole practice in itself helps me a lot. Today I feel confident. Let's suppose, if I am insecure on a content issue, I already feel strengthened in other respects, even though I am still not confident about something, something else gives me more security and I can get it to compensate for what I feel insecure about. Let's suppose, when it comes to content and I'm talking, what I do is to try to get the student's previous knowledge [...].

Sônia emphatically states how her long professional practice and her experience 
have given her more confidence in the biological content knowledge to work with her students. In situations experienced in practice, when her mastery over subject matter knowledge seems insufficient, the teacher cunningly uses some tactics (Certeau, 2014). Faced with a new situation, she brings to the fore students' previous knowledge and mobilizes other knowledge that promotes involvement and participation. Sônia seems to have a confidence reservoir about the biological contents built throughout her experience that allows her to balance the feelings of insecurity in her practice. The tactics used by the teacher indicate the appropriation and modification of the instituted - domain of content - which, in an "almost invisibile way", trace paths of "stubborn, cunning practices $^{17 ”}$ (p. 89) materialized in her pedagogical movements so as to overcome their insecurities.

Sônia's narrative seems to indicate how the appropriation of biological content knowledge allows a certain mastery of the context. In the situations discussed, the knowledge the teacher mobilizes in the pedagogical activity is expressed through specific forms of relationships that it produces and establishes with the world: students' critical education; mastery on the content; and the way she acts in pedagogical contexts. In this sense, Sônia's professional trajectory offers strong indications of how her "ways of doing" reflect the relationship she establishes with the world, with herself, with her students and with her knowledge. Sônia's experiential knowledge, therefore, is not ethereal, as Tardif (2014, p. 11) claims; it is "her" knowledge, related to teaching objects, "[...] with her life experience and her professional history, with her relationships with students in

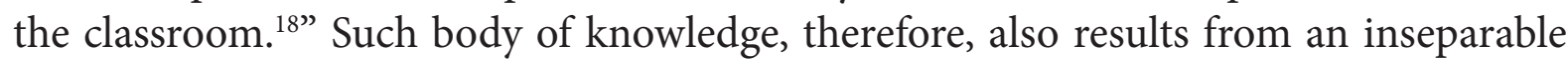
relation with the objects taught in biology classes.

\section{The use of images, schemes and exercises from the textbook}

In this section, in addition to the traits that identify school knowledge, we also try to understand the place and sense that certain teaching procedures occupy in the teachers' practices. In order to elaborate these "ways of doing", we prioritize the enactment of knowledge in action, and also the reflection, capable of promoting changes in pedagogical practice. For this, we foreground the analysis into the category of pedagogical content knowledge proposed by Shulman (1986). As an object of analysis, we bring episodes experienced by two teachers - Sérgio and Nilton - in which the use of images, schemes and exercises were common procedures used by them in teaching situations.

During the presentation of contents, in general, Sérgio asked students to observe images and explanatory schemes in the textbook. In addition, he asked students to read the content of the lesson beforehand at home and to solve the exercises, especially the questions of university entrance exams. During the observations, it was possible to perceive the concern in addressing the content based on biological content knowledge

17 Our translation.

18 Our translation. 
required by vestibular ${ }^{19}$ tests selected by him, as presented below.

As a way to talk about the DNA's action in the nucleus during cell division, the teacher used some animations projected on a television, which showed the transformation of DNA - chromatin, chromosome - during cell division. In presenting the condensation of DNA, he pointed out, analogically, that it was due to the action of special proteins called histones "that act like a magnet". The teacher then asked students: " $[\mathrm{T}]^{20}$ What if I include this video on the monthly test? [...]. So the cell has a cycle of development [showing the animation on the television]: it is born, it grows, that is, it forms, develops and splits". At that moment when he was talking about cell division, Sérgio reported on the entrance exam from the State University of Campinas (Unicamp) that focused on the stages of the division. He explained in detail the "checkpoints" in cell cycle and related those moments to the onset of cancer, because when there is a checking failure at the time of division, tumors may appear. He then continued to address cancer issues such as tumor removal and chemical treatment.

During Sérgio's class, even using video animations, analogies, and making cell division relationships with contextual aspects, the content was approached through expository moments most of the time. Several times, the teacher asked some provocative questions, but only one student interacted with him, the others remained apathetic to the content, but one of them finally asked: "[S] Do cells die?" The teacher promptly replied: "[ T] Yes, some remain alive, others like red blood cells and epithelial cells often die". Returning to the video and presenting cell division, Sérgio drew attention to the role of centrioles, nucleus position, fiber formation and DNA condensation - chromatin shift to chromosome: "[...] They [the centrioles] act like a tug of war, remember? To separate chromatids and ensure balance of genetic information". In this context, he mentioned as an example some syndromes resulting from the imbalance that occurs in the division of the X chromosome - Turner, Klinefelter, etc. Continuing the explanation, the teacher showed on the television some karyotypes related to these syndromes, comparing them with the karyotype of an individual who did not carry them. In the last moments, the teacher asked students to solve the exercises (vestibular questions) proposed in previous classes and asked them to do others, warning that in the next class, he would make the correction and check the notebooks.

The expository "way of doing" used by teacher Sérgio to address "cell division" seems to be influenced by academic education, when expository practices, rather than interactive ones, are more frequent, although they are also used in school. Reproduced in situations of school teaching, these practices seem to limit the production of school

19 The primary and widespread entrance system used by Brazilian universities to select the students admitted.

20 The letter T will be used to indicate "teacher" and S to indicate "student"

21 These "check-points" are related to the cell cycle control system, a biochemical device that operates cyclically, constructed from a series of proteins that interact with each other and that induce and coordinate the essential dependent processes responsible for the duplication and division of cellular contents[...]. In a standard cell cycle, the control system is regulated by interruptions that can stop the cycle at specific strategic control points checkpoints (Alberts et al., 1997, p. 868). 
knowledge. In this sense, the teacher used a few mechanisms that made biological content teachable to his students, that is, the content exposure ceased to create richer spaces for interaction and contextualization of the information addressed. Only in a few moments, he used elements that would bring that information to the universe of students' knowledge, so, in general, he could not engage the class in the discussion.

Although Sérgio tried to translate the biological reference knowledge, using some analogies and questioning students, the intervention did not favor their participation. During the expository moments, students remained silent and, in general, did not make any notes, behaving as spectators. Sometimes, one or another question broke the silence and invaded the ritual of the class, but the teacher's response did not allow the continuity of the dialogue.

Given this episode into account, one might question the relationship between the production of school knowledge and the teacher's "way of doing". In the reported class, we found evidence that the domain of biological content knowledge gains centrality. The teacher wrote down concepts on the board, used animations on television, consulted images and schemes in the textbook, but nevertheless did not involve the pupils to the point of making them interact more intensively with the biological contents. Although there have been efforts such as the use of pedagogical resources, the emphasis on a non-interactive expository approach tends to approximate the curriculum content of non-school production spheres. In other words, student participation can be seen as an indicator of the process of transforming the knowledge to be taught.

Thus, the production of school knowledge is a multifaceted transformation process, since it includes the relationship with knowledge, the relationship with peers and the relationship with students. Accentuating the productive nature of the school, we argue that academic knowledge is interpreted by the teacher (in this case, Sérgio) and translated according to the demands of the context. This translation is guided by principles of autonomy and subjectivity, expressed in his "ways of doing", for it occurs in a specific environment - the classroom - and aims at explicitly school purposes, which is to foster students' learning. School knowledge is, therefore, rearranged into practice and permeated by the combination of different types of knowledge built by the teacher during his personal, formative and professional trajectory.

Another aspect to be highlighted in the teacher's "ways of doing" is the preparation for exams, as Sérgio often proposes the resolution of vestibular questions in his approach to biological contents. The little interaction he establishes with the class seems to be related to the degree of complexity of the subject knowledge of his classes, which is required in these exams. Without judging the value of this approach, it must be acknowledged that it partially meets the needs of the student. If we consider fruitful to include contents that are required in vestibular exams, the same cannot be said in relation to the extent of which these contents meet the sociocultural needs of the class. This option seems to imprison a "way of doing" of expositive nature and with a strong relation to the academic sphere. 
The situation analyzed can be better understood in light of concepts defended by Certeau (2014), when referring to the strength of the totalizing discourses coming from the theoretical places that are behind the concept of strategy. According to the author, strategy is organized by a postulate of power that produces, maps, and imposes theoretical places (totalizing systems and discourses) with the ability to articulate a set of physical places in which forces are distributed. The pedagogical practice of Sérgio seems to carry traits of these totalizing discourses, in which the knowledge conveyed in the vestibular exams influences the pedagogical action. In the case being analyzed, the academic references originating from the initial teacher education, predominated on the "ways of doing" of the school culture. In this sense, we understand that these totalizing discourses interfere on the way the teacher approaches biological content knowledge, marking his practices in terms of scientific and academic knowledge.

In this analysis, which focuses on the knowledge enacted in teaching and teaching objects in the production of school knowledge, we reconstructed the academic and professional trajectory of teacher Sérgio to find some points that help us to understand his "ways of doing". The teacher, in his professional career (eight years), in addition to working in Primary and Secondary School, also works in a post-secondary vocational course in the area of health with specific disciplines in the area of biology, an aspect that may justify the deep and highly-detailed approach on the transmission of information and on the teaching of the subject, which was often related to issues of health.

Another aspect that is worth considering is that his trajectory as a student in Secondary School happened in a "regular" course, at a private school, where students' potentials to be approved in vestibular are paramount to curriculum design. This school path may have contributed to the construction of a teaching reference of the subject of biology and influenced the emphasis the teacher gives to vestibular in his "way of doing". The references of Sergio's school experience in the construction of his professional practice can be understood based on the studies of Tardif (2014). The author emphasizes the temporal nature of teachers' professional knowledge, since most of what the teacher knows about teaching comes from his life history, but mainly from his school history. It is worth mentioning that the entire trajectory of teachers, even before they begin to work, occurs in their own space of action - the school. According to Tardif (2014, p. 85), the first years of professional activity are crucial to the acquisition of skills that contribute to the structuring of professional practice, representing what the author calls "stabilization phase". They are, therefore, types of knowledge developed and used in the course of their professional career in non-linear temporal dimensions, once they cross the territory of practices.

In fact, Sérgio's eight years of teaching show his effort to build references that structure his professional practice and the value he attributes to the biological content, as he said in an interview:

[...] Now, I try to improve my classes each day and to be more focused on activities that make students really interact with the subject [content]. I have some difficulty 
in this regard, I am not such a creative person in terms of didactics, but I have been researching on this, I have read about it, studied it, I'm doing this constantly. [...]. I work with biology in a way that content is explained with all its strands, therefore relating to everything, since biology is interrelated, I can see that way. So you cannot compartmentalize anything.

In explaining his difficulty in making biological content knowledge teachable, Sérgio also speaks of his need to work with the contents, exploring the various nuances so as not to run the risk of compartmentalization. This statement reaffirms elaborated reflections on the episode discussed above. The limitations reported by the teacher are in the pedagogical domain, reinforcing our understanding on how the power of the academic matrix of the biology teacher is materialized in his practice. That is, the focus is on content and high level of details - addressing biology in a non-compartmentalized way - and not on mechanisms that favor student interaction with knowledge and, consequently, learning. It would be worth asking if Sérgio considers that the noncompartmentalization of biology, in itself, already means a didactic effort and, because of that, interaction with the class would not be paramount.

To continue exploring the knowledge enacted in teaching with teaching objects, we focus on the practice of another teacher - Nilton. In the situation analyzed, the textbook was used for the resolution of exercises. Similarly to Sérgio, at the end of the class he recommended solving some previously selected questions that were related to the topic addressed. However, with no emphasis on college entrance exams, Nilton proposed multiple-choice questions, but mainly open discursive issues, which required students to read the content in the textbook. At various times, Nilton charged the pupils with the resolution of the exercises, looked at the notebooks, and then corrected collectively. According to the group, students' resolution of the exercises was part of the qualitative evaluation. We now report how the use of the textbook while solving the exercises was approached by the teacher, allowing to identify the types of knowledge he enacted in the production of school knowledge.

The teacher began his class correcting the activities proposed in previous classes. While speaking, during the correction, of the taxonomic classification of living beings, he used examples focused on the socio-cultural reality of the students, which contributed to their understanding about the contents of the textbook questions. We noticed that students, in answering the discursive questions, transcribed excerpts from the textbook. However, at that moment, in the midst of the answers presented by students, the teacher then explained the content until the class understood the answer and then questioned them again, asking them to reconsider their answers.

Nilton's "way of doing" in solving exercises, a typical activity of school culture, can be understood as a trait of school knowledge production. When students transcribed answers without reflection, the teacher created a space to problematize, using other "ways of doing" that approached the biological content of the students' social context. The way in which the teacher dealt with students' apparent difficulty in understanding 
those contents, retranslating them through new questions and interventions, allowed students to confront their own convictions. This movement also prompted Nilton to produce alternatives, while at the same time, problematizing the biological content. Such reflections allow us to construct two lines of interpretative argumentation. The first one is to recognize the resolution of exercises as a didactic construction; a practical knowledge that originates from the dynamics of the teacher's work and it is, therefore, distinct from other professional knowledge. The second one is to say that the teacher's "ways of doing" when solving class exercises can produce school knowledge.

In the episode we analyzed, as soon as Nilton realized that students were not understanding the exercise, he reflected and acted to solve the problem. The perception that this situation was a challenge of the practice itself triggered search mechanisms to overcome and intervene, mobilizing knowledge from diverse sources. These "ways of doing" performed by the teacher can be analyzed by taking into account that the teacher knowledge enacted, the teaching objects and the context in which professional practice occurs are crossed by "reflection in practice". This concept is related to the idea of reflective professional developed by Schön (1992), which seeks to explain the situations faced by professionals, which are not possible to be solved through technical repertoires. As teaching is permeated by uncertain, unstable and singular situations, the author's arguments start from the actions developed in experiences through which we use tacit, implicit knowledge, making such decisions without thinking beforehand. These are situations in which knowledge does not precede action, but is in action. Rather, they require us to think not only about what we do, but also how we do. Schön addresses this procedure as reflection-in-action and in this text we call it reflection-in-practice.

By realizing the needs arising from teaching situations and seeking to act reflexively from them, Nilton approached pedagogical content knowledge, Shulman's (1986) analytical category, which as we have already mentioned, is the combination of content knowledge and pedagogical and didactic knowledge on how to teach. Articulating Shulman's category with the reflexivity proposed by Schön seems to fertilize the examination of the knowledge enacted in teaching for the production of school knowledge. The dialogue with Shulman allows us to recognize that certain teaching situations require the teacher to make adjustments, considering the context and the students' educational needs. To this end, it mobilizes tacit knowledge while reflecting on the daily actions of its practice, whether it is instigated by interactions with students or externally motivated by other subjects. It is worth mentioning that this process demands from the teacher the predisposition to constantly reflect on their practice, in a collective or individual way, so as to be able to intervene.

The questions addressed to the teachers in this research undoubtedly provoked reflections that, analyzed at this moment, allow us to understand the knowledge enacted and the relation with teaching objects, for instance, when we asked Nilton about how he perceived his pedagogical action:

[...] knowledge is dynamic, I also believe that things in our lives have to follow this path 
and every lesson is a different learning [...]. How much do I learn by giving classes? Sometimes I learn more than picking up the book at home and researching, [when] I put it into practice and approach that with students, I ask myself, "Is that so? Is it working? Is the theory the same?" [Therefore], I think we [the teacher] are never ready $[\ldots]$.

So it's something that passes [goes beyond] knowledge, it goes beyond technique, it has to have involvement, feelings, we must have feelings impregnated to our practice so as to overcome, to modify, to achieve something, and to make a theory work. The university is technical, so if "a student is talking too much, change his seat, talk to him before class", but talking to someone is not something you learn because you read a book. There are more tools, more situations there to develop that dialogue, it is you as a person, dealing with knowledge of the world, from various sources.

Nilton's narrative dialogues with Shulman's process of pedagogical rationalization (1987), once it reveals his understanding of his own practice, admitting that professional practice is not limited to the content domain. For the author, this process of reasoning and pedagogical action consists of a cycle, not exactly linearized, of stages or phases that involve the critical understanding of what will be taught, the pedagogical transformation of content, instruction - teaching activity itself - evaluation of the process that will trigger, consequently, in the reflection, generating a new understanding of the purposes, the contents taught and the aspects linked to them. For Monteiro (2007, p. 194) "The teaching process begins when the teacher approaches the object to be taught and appropriates it, which will generate his understanding. Based on that, they elaborate and develop teaching ${ }^{22}$ ". Recognizing that teaching contexts are also sources of new learning, Nilton realizes the essential transformation that biological contents must undergo during instruction to meet the development of students' skills and educational needs. For him, the pedagogical practice experienced in teaching situations allows one to see clearly if their attitude of making scientific knowledge teachable is coming to fruition. In this movement, Nilton reflexively evaluates his professional practice, provoking a new understanding of the contents, the ends and the means to, once again, teach these contents.

While commenting on the feelings that motivate the adoption of new actions in pedagogical practice, Nilton also exposes the knowledge approached in relation to the biological contents that he teaches. When stating that the professional exercise of teaching goes beyond usual techniques and the knowledge of the content to be taught, it shows that, in order to overcome difficulties, to change practices, "to make the theory work", it is necessary to have desire and personal involvement. This testimonial makes us understand the relationship this teacher establishes with the biological content knowledge and the senses and values that he attributes to the choices and decisions that he carries out in his practice. These meanings and values are, therefore, propellants of his action and are implicit in the production of school knowledge in classroom contexts.

22 Our translation. 
In order to continue this analysis, it is necessary to return to the transcripts of Nilton's classroom observation. The lesson observed ended before the exercise was completely corrected, which led the teacher to advise that, in the next class, he would check the notebooks and continue the correction. Regarding this aspect, it is important to consider that, although the notebook was seen as an element to engage students in the resolution of activities, besides an instrument of qualitative evaluation, its use could reinforce literal transcriptions without any reflection of what was being written down by students. For example, we noticed in previous classes, and also in this one, that students often copy the answers of their activities from their classmates' notebook, sometimes during the teacher's explanation, which would guarantee extra score in the evaluation of the teaching unit. These situations require agreements previously established with the students so that the evaluation processes do not compromise learning. It should also be considered that exercises, as well as notebook checking for control and/or reinforcement purposes, are expressions of the school culture "[...] determined by the imperatives that derive from this teaching function $[. . .]^{23}$ " (Forquin , 1992, p. 33).

In the observations conducted in Nilton's class, we verified that, in addition to the biology textbook, he started or concluded the lesson with the reading of a short reflective text, a fact that was very pleasing to the students, to the point that they would remind the teacher or complain in classes when this procedure would not happen. Such "way of doing" seems to us relevant, because it allows us to report to the tactics referred to by Certeau (2014). Given the context in which curricular settings leave no room for thinking and talking about other aspects of human life, beyond the strictly considered biological content, the teacher has created a context for other discourses. Thus, although there was no time for participatory debates about the text presented, Nilton created in the classroom a space that allowed students to think about other questions.

\section{The construction of explanatory schemes or drawings to produce syntheses of teaching contents}

School routines are made up of seemingly expendable rituals with an inattentive look. However, the lessons observed during research revealed that such rituals conceal a complex combination of "ways of doing", that is, actions adjusted by teachers in the contingency of practice, in order to make biological content knowledge teachable. This reflection favors dialogue with Forquin (1992) when he emphasizes that school education, in order to make knowledge transferable and engaged, must submit this knowledge to a process of reorganization and restructuring through the intercession of "mediating devices". In our understanding, this process occurs through the association of a set of "ways of doing", used articulately in practice and it becomes powerful to favor learners' understanding of the learning object. Therefore, the didactic explanation must consider not only the students' knowledge, "[...] but also the status of the knower, the status of what is taught and of the teachers, their respective position with regard to the

23 Our translation. 
knowledge and the institutionalized form of the relationship that exists between one and the other in such a social context ${ }^{24}$ (Forquin, 1992, p. 33).

The "morphological and stylistic traits" pointed out by Forquin (1992) are constituted by mediating devices through which it is possible to identify school production. These devices, thus, form a set of actions planned and coordinated by the teachers during teaching procedures, which are previously selected and tacitly organized. These selections are permeated by contingencies of different nature, involving the students' knowledge, the dynamics of the class, the way they react to the pedagogical actions, the sociocultural context in which they are inserted, all of which demands to the teacher a certain wisdom to combine the "ways of doing" that best fit the situation found at that moment. Therefore, although some "morphological and stylistic traits" are already consolidated in the school culture because they are already produced knowledge, the ways in which teachers use them and conform them to everyday situations, when negotiating meanings that potentialize students' understanding of biological contents, reveal a personal and anonymous production of school knowledge within teaching practices.

Following Forquin's (1992) ideas about the "morphological and stylistic features" of school culture, we can say that the production of knowledge from teaching practices can occur when teachers make use of mediating devices and, combined with other "ways of doing" negotiate meanings that boost pedagogical action. Through the observations conducted during the investigation, we can highlight two brands of this production that have appeared frequently: the construction of explanatory schemes and drawings to produce reviews or syntheses of the contents approached. In the episode described below, recorded during one of Nilton's lessons, these mediating devices appear mixed up with other teaching procedures, revealing how the teacher mobilizes a plethora of knowledge to specifically produce school knowledge:

[T] Before we talk about reproduction, let's recall some of the basic structures of a fungus body [goes to the picture] ok? [turns to the group] The fungus is formed from what? [break]

[S1] Membrane...

[T] Not the cell, I mean, the fungus [turning to the student].

[S2] It's filamentous.

[T] Filamentous! These filaments, what are they?

[T] They are... the...

[S] The ...

24 Our translation. 
[T] It's the ... the ... [he smiles, goes to the board and writes the word "Hyphae"].

[S2] It is something that reproduces asexually.

[T] [Turns back to the class and asks] The? ...

[S(s)] Hyphae!

[T] The hyphae, the hyphae, the hyphae people!!! [smiling]. They can be of two types, remember? What are the types of hyphae? Coenocytic or ... [nodding as if he had heard the answer] septate, septate as it is, septate!!! So, look, let's look at this [drawing on the board]: the hayphae, it is a piece, a structure of the fungus, that will contain the plasma membrane, the cytoplasm and the nucleus. If it is opened [showing the drawing], with a direct passage, it is coenocytic. If it has a septum [turns to complete the drawing], it is septate. OK? Quiet? Has everyone visualized? So, today we are going to study reproduction. Reproduction in fungi is not different from other living things, it can be of two types of reproduction. Which are they?

[S] Asexual and sexual.

\section{$[\ldots]$}

[T] So, let's go [begins to draw a scheme on the board]: asexual does not have fusion of gametes. So this reproduction happens in two ways, it happens by [writes on the board and then back to the class] fragmentation. What is fragmentation, fragmenting? What do you imagine? How is this fragmented reproduction or fragmentation?

[S] It breaks [the teacher demonstrates removing the marker lid which was in his hands] [students laugh, and the teacher nods affirmatively].

[T] Broke, split, fragmented. [...] Then, [He turns to the drawing on the board] we have the hayphae, it suddenly fragmented, one piece falls on this side and another piece on the other side [drawing on the board], this one grows here and that other one grows. It's more or less how people talk:

[T] You get home, there is that wonderful plant, all beautiful, and then someone says [dramatizing]: "Oh, give me a seedling." What do you have to do? Do it soon, otherwise, what happens? [smiling]. The plant inexplicably dies. [Turning to the class, he insists] And what's this seedling? How do you plant it?

[S] We just do ...

[T] Pull a piece of the plant and put it on the ground and there it will develop the bud... [points to a student as if he had realized the understanding of what he was saying, nods 
affirmatively] is that [which kind] ... of reproduction?

[S] Asexual.

[T] Asexual! Depending on the species, there's a bunch of the techniques you have to do. [...] So fragmentation is which form of reproduction?...

$[S, T]$ Asexual!

[T] One will be the clone of the other, okay? So far so good?

[...] [The scheme drawn on the board during the lesson]

[T] Quick review for us to understand here [make a brief recap from the drawing made on the board].

Based on the transcript presented above, it is possible to perceive that the teacher constructed his argumentation by means of a brief review on the contents approached in the previous class. Using this device, the questioning routine, from which he dynamically produced an explanatory web in which the students' participation gained centrality, allowed him to introduce knowledge related to the reproduction of fungi. His argumentation began to take shape as he constructed explanatory schemes, writing key words on the chart, which later gave way to the illustrative drawings of the reproductive cycle.

In addition to the syntheses of the contents addressed and the construction of explanatory schemes or drawings, which are "morphological and stylistic traits" typical of school culture (Forquin, 1992), other mediating devices described by Forquin can also be identified in Nilton's exposition. When comparing the sequence of content presentation of the class with that of the textbook, it is possible to identify some different paths. The drawings, schemes and syntheses are common "ways of doing" at the school context and they represent Nilton's didactic elaborations, altering the sequence proposed in the textbooks. We find in these "ways of doing" possibilities of dialoguing with Shulman (1987), when he identifies the sources of teaching work, especially educational materials and structures. Those are typical school production, since they are related to the practical dimension in which the biological content knowledge, in this case, is transformed. We can therefore point out some aspects identified in the lesson: Nilton contextualized, in the students' everyday knowledge, stories related to beliefs, to exemplify asexual reproduction through fragmentation and, by narrating the anecdote about seedling, used dramatic resources to give life to speech characters; in announcing certain concepts, he used various synonyms, starting from the simple to the complex, and vice versa; he walked continuously throughout the classroom, which fostered students' attention; and repeatedly used variations of vocal stimuli and body language (gesticulating arms and hands). These traces allow us to identify the construction of school knowledge, since the 
approach of varied types knowledge allowed a retranslation of biological content.

In his narrative, Nilton highlighted aspects of such production teaching knowledge, translated into "ways of doing" in his professional practice:

There is a lot we learn in theory at university and when we come to practice, it [the theory] is not what we expected, it is not what we saw. So, nowadays we are shaping our practices for that [the context]. [...] the adaptations we go through as a professional help us to achieve our goals. When we follow only the theory from the university we do not get ready, we only get ready later. [...]

The main competence in my view [that I acquired in the course of my professional career] was the refinement in methodology, in didactics, so as to be able to involve students with the objective of the class, which is very difficult. Sometimes I get frustrated at home when I cannot give that class in which I expected to get " $x$ " and I cannot get anything [with emphasis]. [...] So, I believe that teaching comes with the experience itself, of us perceiving things and being able to change across time to reach those goals. I have achieved that during these years of refinement, of classroom practice [with emphasis]. [...] I think I've improved a lot in those years of experience, dealing with several people, from various social classes, with various worlds...

In his testimonial on professional practice, we find evidence that Nilton distinguishes biological content knowledge learned at university from the school subject matter with which he operates. Nilton refers, above all, to the need for adaptations to be made by the teacher on a daily basis to make "theory" (biological contents) a teachable knowledge. These considerations suggest his understanding that, in the teaching exercise, professional knowledge is produced to conduct the work with students. The teacher also recognizes the school as a place for professional development in which, through the production of practical knowledge, there is a continuity on initial teacher education. Among the teaching knowledge produced in his professional career, the teacher emphasized the pedagogical knowledge acquired through reflection, which seems to indicate a search for new forms of intervention that ensure satisfactory results of his pedagogical action. We can understand that, according to Schön (1992), these types of knowledge are the result of a reflexive process about the already developed action or, still, about an action that is being planned. It differs therefore from what occurs during the action (reflection-in-practice). Considering the theoretical perspective presented by Shulman (1986) and Schön (1992), we can claim that by reflecting on his practice, Nilton exemplifies the development of "pedagogical content knowledge". Also, emphasizing that such knowledge comes from experience, we understand, based on Tardif (2014), that in his professional trajectory, he has learned from peers and from different contexts.

\section{Final remarks}

In this article, we aimed to understand the range of knowledge approached by biology teachers in their daily practices and, to what extent they generate the production of school knowledge. Combining data from questionnaires, interviews and field notes 
from three biology teachers, we examined how specific types of knowledge enacted in teaching practices are built in relation to teaching objects. To do so, through the elaboration of subcategories - approaching biological contents in the reading of the textbook; the use of images, schemes and exercises from the textbook; and the construction of explanatory schemes or drawings to produce syntheses of biological contents - we present the production of school knowledge embedded in teachers' "ways of doing". By the contingent nature of the action, these "ways of doing" explicitly unveil improvisation, in which teachers combine different mediating devices, producing reconfigurations in the presentation of biological contents.

The analytical commitment, consistent with the subjectivist-interactionist approach, took into account concrete situations, mindful of teachers' personal competences and their "[...] ability to cope with more or less transient and variable situations ${ }^{25}$ ", as pointed by Tardif $(2014$, p. 49$)$. In this sense, in the routine of seemingly equal teaching practices (or following a pattern adopted by many teachers) different traces arise, which constitute movements resulting from a set of pedagogical actions organized and coordinated for teaching purposes. In addition to the schemes of action, which are used by teachers to present knowledge in various ways, they are also concerned with classroom management. These two aspects of the teaching exercise seem to be permanently associated, as they condition the result of their action and students' content learning.

Regarding the "morphological and stylistic traits" characteristic of school culture, as analyzed by Forquin (1992), we understand that teachers mobilize varied knowledge, combines different "ways of doing", involving students' everyday knowledge, body language stimuli, contextualization, etc. to retranslate the biological contents. In this way, it is possible to consider that when the teacher recognizes differences between the biological knowledge learned at the university and that of the school subject, even without being aware that they produce knowledge in the professional exercise, the teacher prioritizes a knowledge that is proper to school culture. Such body of knowledge is translated in their practice by the combination of different "ways of doing" that favor students' content learning.

In this sense, when selecting favorable devices to approach biological content, it is possible to perceive that classroom management, supported by experiential knowledge, creates traces through the combination of disciplinary, curricular and professional knowledge (Tardif, 2014), allowing new elaborations. These elaborations, while providing students' participation and involvement, also enable retranslations of biological contents, as they are permeated by students' previous knowledge, and also by the problematization and contextualization of these contents. We show that, at the epistemic level, the production of school knowledge, hidden in the routines that constitute the school culture, exposes the plural and heterogeneous character of teacher

25 Our translation. 
knowledge originated from various sources, and enacted to serve different objectives, situations and contexts, and to respond to peculiar purposes of teaching.

In approaching Certeau's formulations, we can understand that this production of school knowledge, nourished by experiential knowledge, means an inventiveness of the teacher and comes from tactics used to challenge the strategies instituted in other social spheres. We identified "ways of doing" which indicate the use of more specific experiential knowledge by biology teachers that, when articulated to other types of knowledge, configure forms of production of school knowledge. In an anonymous, subjective and personal way, teachers interpret, select, retranslate, restructure, reorganize and transform contents. Thus, by reversing power relations, teachers' "ways of doing" assume meanings not authorized by prescriptive guidelines. Therefore, it is in the realm of practice that these tactics materialize inventions, which resist and contradict curricular prescriptions, even when it comes to the use of textbooks. It is possible to interpret that it is within the school conditions that teachers make use of "subtle ways" to face these imperatives. We understand that these "escape routes" shape "ways of doing" at the heart of these constraints, consolidating experiential knowledge.

Admitting that the "ways of doing" are the result of inventions in relation to prescriptions has epistemic implications. The study gathers evidence that aims at the knowledge and, therefore, ratifies the productive character of teaching practices. On the one hand, the presentation and analysis of the empirical material of this investigation, in dialogue with theoretical constructs, expose analytical contradictions found in the literature on the nature of knowledge and school knowledge. The insistence on denying that there is production in school arises not only from the technicist-rational formulations that overestimate both scientific knowledge and transmissive techniques, but also from curricular studies that, in macrosocial perspectives, interpret school work as a symbolic reproduction of social class relations. In contrast, in situating this research on the subjectivist-interactionist approach, we show that teachers are not merely technical subjects, reproducers of other knowledge and practices, as monolithic derivations of those. On the other hand, if the "ways of doing" are instances of school knowledge production, such interpretation is brought in this text because it was possible to put it into dialogue with the theoretical contributions on curriculum and the epistemology of teaching practice, with the contribution of Certeau on political action in everyday life. Taking into account what is discussed by Tardif (2014) and Gauthier et al. (2006), teachers are social actors who perform their work in human interactions, in the spaces of intersubjectivity, the examination of how teacher knowledge is developed is enhanced when we include the power relations that cross the professional action of these subjects, whether with different types of knowledge, or with other actors that make up the intricate web of these social interactions. In this way, the complex nature of teaching and the knowledge that it produces were faced as an epistemic object that is rooted in political action.

Finally, the research carried out contributes to the studies that treat, in a separate 
and indistinct way, the production of teaching knowledge and the curricular inventions in the teaching practices of science and biology teachers. If the experiential knowledge leads teachers to invent "ways of doing" within the constraints of the profession, further research may invest in understanding this everyday invention through the lens of the relationship between teachers and students. In addition, it is also necessary to ask how newly trained teachers address the curricular prescriptions, since, when compared to the subjects of the present study, they cannot rely on experiential knowledge. It would also be worth to understand up to what extent the theoretical repertoire presented in this text could address the questions made by Feldens (1986). Certainly, both the educational field and, in particular, science education, have empirical records scrutinized by theoretical encounters constructed over these thirty years, ever since the state of the art delineated by the author.

\section{Acknowledgements}

The authors express their gratitude to the Research Funding Agencies - CNPq, CAPES and FAPERJ - and to the State University of Southwest of Bahia for the support received to carry out the research that originated this article.

\section{References}

Alberts, B., Bray, D., Lewis, J., Raff, M., Roberts, K., \& Watson, J. D. (1997). Biologia Molecular da Célula. 3. ed. Porto Alegre: Artes Médicas.

André, M. E. D. A. (2003). Etnografia da prática escolar. 9. ed. Campinas, SP: Papirus.

Bonfim-Silva, V., \& Carmo, E. M. (2016). Entre saberes docentes e Ensino de Ciências e Biologia: Reflexões sobre a produção acadêmica. Revista de Ensino de Biologia da Associação Brasileira de Ensino de Biologia - SBEnBio, (9), 1471-1481.

Borges, C. (2001). Saberes docentes: diferentes tipologias e classificações de um campo de pesquisa. Educação \& Sociedade, 22(74), 59-76.

Carmo, E. M. (2013). Saberes mobilizados por professores de Biologia e a produção do conhecimento escolar. (Tese de Doutorado em Educação). Programa de Pós-Graduação em Educação da Universidade Federal Fluminense, Niterói, RJ.

Certeau, M. (2014). A invenção do cotidiano: 1. Artes do fazer. 22. ed. Petrópolis, RJ: Vozes.

Colinvaux, D. (2008). Aprendizagem: as questões de sempre, a pesquisa e a docência. Ciência em Tela, 1(1), 1-11.

Confortin, R., \& Caimi, F. E. (2017). Revista Brasileira de Pesquisa em Educação em Ciências, 17(1), 157-181. https://doi.org/10.28976/1984-2686rbpec2017171157

Feldens, M. G. F. (1986). The state of the Art in Teacher Education in Brazil. Journal of Education for Teaching, 12(1), 85-96. 
Forquin, J. C. (1993). Escola e Cultura: as bases sociais e epistemológicas do conhecimento escolar. Porto Alegre: Artes Médicas.

Forquin, J. C. (1992). Saberes escolares, imperativos didáticos e dinâmicas sociais. Teoria e Educação, 1(5), 28-49.

Gauthier, C., Martineau, S., Desviens, J., Malo, A., \& Simard, D. (2006). Por uma teoria da pedagogia: pesquisas contemporâneas sobre o saber docente. 2. ed. Ijuí: Unijuí.

Lessard, C. (2013). Entrevista com Claude Lessard: reflexões sobre a valorização docente na província do Québec, Canadá. Revista Educação em Questão, 46(32), 226-240.

Lopes, A. C., \& Macedo, E. (2011). Teorias de currículo. 1. ed. São Paulo: Cortez.

Megid-Neto, J., \& Fracalanza, H. (2003). O livro didático de ciências: problemas e soluções. Ciência \& Educação, 9(2), 147-157.

Minayo, M. C. S. (2014). O desafio do conhecimento: pesquisa qualitativa em saúde. 14. ed. São Paulo: Hucitec.

Monteiro, A. M. (2007). Professores de história: entre saberes e práticas. Rio de Janeiro: Mauad X.

Nunes, C. M. F. (2001). Saberes docentes e formação de professores: um breve panorama da pesquisa brasileira. Educação \& Sociedade, 22(74), 27-42.

Schön, D. (1992). Formar professores como profissionais reflexivos. In A. Nóvoa (Coord.). Os professores e a sua formação (pp. 77-91). Lisboa: Don Quixote.

Shulman, L. (1987). Knowledge and teaching: foundation of a new Reform. Harvard Educational Review, 57(1), 1-22.

Shulman, L. (1986). Those who understand: the knowledge growths in teaching. Educational Reseacher, 15(2), 4-14.

Tardif, M. (2014). Saberes docentes e formação profissional. 17. ed. Petrópolis: Vozes. 
Edinaldo Medeiros Carmo

(1) https://orcid.org/0000-0002-1594-8983 Universidade Estadual do Sudoeste da Bahia

Departamento de Ciências Naturais

Vitória da Conquista, Brazil medeirosed@uesb.edu.br

Sandra Escovedo Selles

${ }^{\circledR}$ https://orcid.org/0000-0002-7921-0478 Universidade Federal Fluminense

Niterói, Brazil escovedoselles@gmail.com

Submitted on 30th March 2018

Accepted on 3rd April 2018 Published on 27th April 2018 